\title{
Feeding of the hungry by Jesus (Lk 9:10-17) as model for addressing the COVID-19 hunger challenge in Anambra State, Nigeria
}

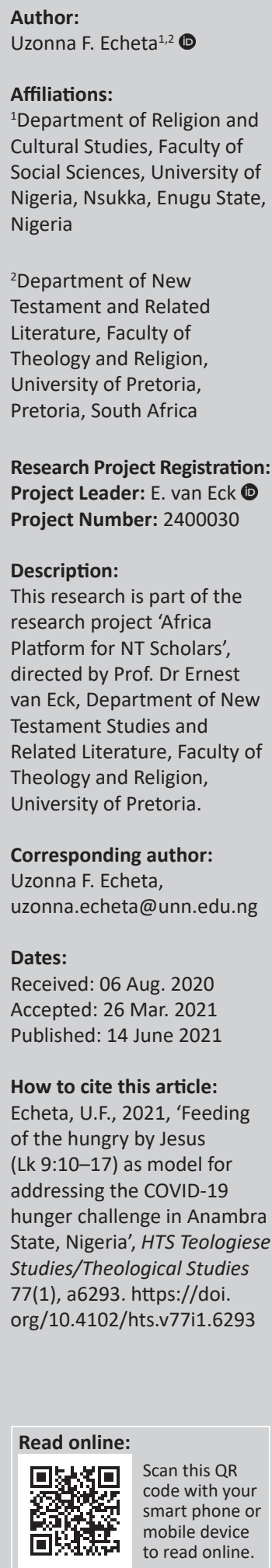

Feeding of the hungry is a theologically significant miracle in the ministry of Jesus, little wonder it is recorded by all the gospel writers (Mathew, Mark, Luke and John). In Judaism, feeding the hungry and hearkening to the needs of the poor and vulnerable are core demands of the religion. In fact, such a service far outweighs any service that anyone could render to God. The hungry people, who Jesus attended to, are desperately hopeless and Jesus exemplified heightened selflessness, love and care. The coronavirus disease 2019 (COVID-19) hunger is very peculiar and severe. The hunger is a result of the lockdown of commercial activities, which paralysed businesses and grounded economic activities to a halt, and placed both the rich and the poor in the same boat. The appalling situation that prompted this research is that, whilst food and monetary donations are being made by concerned philanthropists, hungry people still abound in the state because of ineffective strategies in the sharing of the palliatives. This research adopted a historical-critical method of analysis and the new method in New Testament interpretation in interpreting the pericope (Lk 9:10-17). Focus was placed on the core text; parallel passages are compared to bring out the original meaning of the text and how it can be pragmatised in Anambra State. Results showed that Jesus effectively satisfied both the physical and spiritual hunger of the crowds (hoi ochloi). He was able to draw the attention of his disciples to the need to cater for the hungry; there is surplus and no wastage. Additionally, compassion, love and selflessness are seen to be important virtues needed for equitable distribution of aid to the poor. If Jesus' strategies are adopted where applicable, Anambra State can be hunger-free.

Contribution: This article reveals that Jesus effectively and holistically fed a hungry crowd of 5000 men. Their psychological, emotional and physical hunger were satisfied. Jesus' strategies were contextualised within Anambra state where the COVID-19 lockdown generated much hunger. The article falls within the scope of Africa Platform for NT scholars.

Keywords: Jesus; hunger; malnutrition; poverty; COVID-19; palliative.

\section{Introduction}

Hunger and poverty escalated in Anambra State during the coronavirus disease 2019 (COVID-19) pandemic. Coronavirus disease 2019 (name given by the World Health Organization [WHO]) is a disease caused by an infectious virus, which spread amongst humans. It began to spread in an uncontrollable and unprecedented manner and its effect has led to economic downturns and devastations on individuals and families. This is a novel virus and the fifth one to affect humans (Liu, Lin-Kuo \& Shih 2020). From the report given in ActionAid by Tripathi (2020:1), a vivid picture of how COVID-19 poses a threat to global peace and worsens the hunger situation, is evidenced. It goes on to explain that whilst hunger affects every part of the globe, although not at the same magnitude, vulnerable peoples and nations suffer more impoverishment. The COVID-19 pandemic has ravaged nations, crippled global economies and left both the rich and the poor crying out for aid. The report is further amplified by ReliefWeb (2020:1) who indicated that more than 30 of the world countries in the global south are struggling with hunger. The COVID-19 food scarcity is likely to cause a food crisis and Anambra State in Nigeria will not be spared. In fact, Beasley (2020:1) projected a hunger pandemic if urgent action is not taken.

Hunger challenges have become a worrisome phenomenon especially in recent times and has increased slowly but steadily in the last three years. The United Nations' Food and Agriculture Organization (FAO), the International Fund for Agricultural Development (IFAD), the United Nations Children's Fund (UNICEF), the World Food Programme (WFP) and the WHO have all

Copyright: (C) 2021. The Authors. Licensee: AOSIS. This work is licensed under the Creative Commons Attribution License. Note: Special Collection: Africa Platform for NT Scholars, sub-edited by Ernest van Eck (University of Pretoria). 
been at the forefront of fighting hunger but its persistence is obvious. It is estimated that 820 million people are hungry globally (FAO 2019). World hunger is synonymous with malnutrition, undernourishment and poverty. Hunger thrives generally with poverty, climate change, conflicts, natural disasters and environmental dispositions.

A real practice of Judaism demands that the hungry people should be fed (Schwartz 2017:4). This all-important practice is regularly mentioned in Jewish gatherings especially on the Jewish holy day, the Yom Kippur. The Torah Haggadah and the Talmud all emphasise feeding the hungry as a practice of fundamental and utmost importance to God. Feeding the hungry was likened to providing service to God and is in fact, the greatest service to God (Is 58:6-8).

Elochukwu (2016:3) observes that hunger in Nigeria is caused by bad governance, misplacement of priority, lack of skill for gainful employment and limited productivity. These factors account for the reason why hunger and poverty have remained a challenge in Nigeria until the present. Even though Nigeria suffered poverty and hunger before now, Anambra State fared better than some other states judging by available records. Nwafor (2017:1), for instance, reported that the state has the lowest incidence of poverty. The reason why Anambra fairs better than most other states of Nigeria is because of the commercial activities of some towns like Onitsha and Nnewi, which boost its economy. Anambra people have the culture of 'being their brother's keeper' and partnering with the government. The governor of the state, Willie Obiano, declared that the strength of the government rests on its partnership with people (Nwafor 2017:1).

Notwithstanding the poverty status of Anambra state prior to the emergence of COVID-19, the indigenes are currently suffering COVID-19-inflicted hunger because of the lockdown measures, which shut down most commercial activities. Lockdown of businesses created a very unconducive atmosphere both for the well-to-do and the previously poor. The hunger-driven Anambra people trooped out from their homes and various cities, meaning they defied the lockdown order. They went out in search of food for their families and complained that hunger resulting from the lockdown was becoming more severe than the pandemic.

This study specifically investigates the COVID-19 hunger challenge, which emerged largely because of the lockdown measures. The study uses the Lucan account of the feeding of the hungry by Jesus as a guide to alleviate the hunger challenge in Anambra State. The historical-critical exegetical method and the new exegetical method in New Testament interpretation were used here. The author's historical situation, his literary genre and the possible date of the composition of the book and the social setting of the book are all examined. The recipients situation and how the text affects Christians in terms of faith and spirituality in the 21st century were taken into consideration (Van der Merwe 2015). The meaning of key words and phrases in the text are then explored. Lessons drawn from the text are contextualised within Anambra contemporary society.

\section{Hunger challenge reviewed}

Hunger has been a world threat that requires a definite and decisive solution and this is widely discussed. In this section of the study, hunger and poverty are looked at from diverse perspectives, namely food insecurity, undernutrition, malnutrition and particularly as it occurs in Judaism, Nigeria and the state in question.

Schwartz (2017:7) opines that feeding hungry people surpasses fasting and prayer in importance. That is why in most religious gatherings such as the Yom Kippur, people are reminded of this law as Isaiah 58:6-7 is read. This very fundamental principle of Judaism is widely emphasised in the Talmud, which states that 'providing charity for poor and hungry people weighs as heavily as all the other commandments of the torah combined' (Schwartz 2017:7). During the Passover also, the Talmud and the Haggadah are read to the conveners stressing that food should be shared with both the Jews and everyone else because God is the father of all (Mt 2:10; Pr 25:12). Torah laws mandate people to leave corners of the field whilst harvesting, so that hungry people can benefit from their farm ( $\operatorname{Lv} 19: 9 ; 19 ; 10 ; 25: 2$ 7 and $\operatorname{Pr} 17: 5)$.

Walter (1957:1) reasons along the line of spiritual hunger, which he relates to deep desire or a longing for fellowship with God. Satisfaction and happiness for God's children can be experienced when they are in fellowship with God (Mt 5:6; Lk 15:3). Walter's contribution is lopsided even though logical, but to underrate the existence and effect of physical hunger is dangerous. Physical hunger can deter people from hungering after righteousness. An Igbo saying goes like this: a naghi ebu onu eto ja [you do not worship God with an empty stomach].

Butler (1991) avers that hunger is a very important concept in the Bible but should not be regarded as just a desire for food. The theological significance is shown in Exodus 16:3 where God used hunger to humble the Israelites and make them hungry for his word (Dt 8:3). The cessation of hunger is frequently associated with God's salvation. The end of hunger is part of the blessedness of the redeemed ( $R v$ 7:16). Jesus promised absence of hunger for those who came to him for they will be satisfied. He stressed the need for people to feel hunger and thirst for righteousness.

Macalister (1939) gives the etymology of hunger as ra'abh, limos and peinao with the overall meaning of physiological awareness that the stomach is empty and needs food, starvation and famine or scarcity of food as the case may be and depending on contextual usage (Ex 16:3; Is 49:10; Dt 8:3; Jr 38:9; Ezk 34:29). Hunger, according to Macalister, describes a poverty situation that is prompted by laziness and idleness. The absence of which leads to happiness in future ( $\operatorname{Rv} 7: 16)$.

Discussing further from the perspective of Judaism, Moss (n.d.:1) challenges the idea of spending huge amount of money on building synagogues, Jewish schools and academic institutions. Spending money on taking care of the suffering and the poor yields more dividends. It is the torah's demand that we should use the income God gives us to better his 
world and distribute part of it to the needy. The word 'charity' in the Hebrew language is tzedakah meaning 'justice'. It is therefore logically and morally right to give to those in need. The problem with Moss's suggestion is that he holds a rather extreme position. Both feeding the hungry and building educational institutions are necessary. He cites this story by the sages (Midrash on Ps 118):

When you are asked in the world to come, what was your work and you answer, 'I fed the hungry' you will be told this is the gate of the Lord, enter into it, you who have fed the hungry. (v. 17)

Da Silva et al. (2019:2) report that in 2019, 820 million people did not have food to eat as compared with 811 million in the previous year. The increase has been progressing for three years, implying that the target of the United Nations' Sustainable Development Goal of Zero Hunger by 2030 may not be acheived (Da Silva et al. 2019):

Together, Africa and Asia bear the greatest share of all forms of malnutrition, accounting for more than nine out of ten of all stunted children and over nine out of ten of all wasted children worldwide. (p. 2)

Countries with poor economic growth face more hunger. Africa for instance, especially the eastern part, has an alarming rate of hunger and is actually the worst in the world. There is a need for re-strategising in the light of this escalating development. A multisectoral collaboration involving the heads of the United Nations' FAO, the IFAD, the UNICEF, the WFP and the WHO would be useful.

Ukpokolo (2016:112) avers that poverty varies in Nigeria along the urban and rural divide. Poverty exists in Nigeria and this is worrisome. However, poverty is relative to areas in different magnitudes. The level of the sting of poverty in Northern Nigeria is higher than in the southern part. Similarly, rural women feel the weight more than those in the urban cities. In Nanka, a town in Anambra State, Ukpokolo argues that the women of Nanka, like every other in the state, put in many efforts to improve the financial security of their households.

Pfeiffer, Vos and Rea (2005:821) present three uses of hunger in the Bible: (1) from a physiological perspective to imply starvation and famine (Ex 16:3; Lk 15:17), (2) it can also simply refer to normal physical desire for food as used in Romans 12:20 and (3) as a desire for spiritual fulfilment and sustenance.

Willis (1915:1) approaches hunger from a critical dimension and looked at it as it relates to the personality of Jesus. The Greek words that describe hunger in the New Testament are limos which occurs not less than 17 times, and the other word is peinan which is referred to in six places. Jesus had two experiences of hunger, which expose his human nature and the physical and spiritual importance of this concept in his ministry. Immediately after his temptation, Jesus suffered hunger (He hungered; see Mt 4:2 and par.; Mk 11:12 and par.). John did not record the temptation but accounted for Jesus' experience at the point where he encountered the Samaritan woman. It is very glaringly shown in John because Jesus was so weakened and tired (Jn 4:6-8) that his disciples went to find food for him.

The FAO, WEP and EU (2018) report that about 815 million people of the 7.6 billion people in the world or $10.7 \%$ were suffering from chronic undernourishment in 2016. These people live in lower-middle-income countries. World hunger, for them, does not necessarily mean food insufficiency but that so many people in the world still lack sufficient income to buy food or lack land to grow the food. Achieving food security involves a simultaneous occurrence of these four dimensions, namely: (1) physical availability of food, (2) economic and physical access to food, (3) food utilisation and (4) the stability of those other dimensions over time. The factors that cause hunger include political instability, food and agricultural policy, poverty, the principal cause, conflict and climate change. There is a prevalence of undernourishment in Southern Asia, which includes India, Pakistan and Bangladesh although Eastern Asia has shown a reduction. Africa has no record of improvement and so is the worst affected.

Beasley (2020:2) shows serious concern that COVID-19 is likely to lead to a global hunger pandemic. Before the arrival of COVID-19, many countries had been battling with hunger. With the socio-economic impact of the virus, the situation is largely worsened. The WFP forecasts that 300000 people could starve to death in the next three months. A hunger pandemic is looming and is a worse pandemic because it could engulf over a quarter of a billion people whose lives are already exposed to immediate danger. Therefore, urgent action is needed.

Echeta (2020) opines that hunger and poverty exist in Anambra State, even though at a reduced rate. The reason why the severity of hunger is lessened is because Anambra indigenes are very enterprising, industrious and commercially oriented and this enables them to have a strong financial backing. Ejikeme et al. (2017:29) lend support to Echeta's view on the people's commercial inclination by saying that Onitsha (one of the mega cities in Anambra) is reputed as the biggest commercial market in West Africa.

Elochukwu (2016:1-5) examines poverty and malnutrition and the effects of hunger on the individuals in Anambra and the general economy. He draws an association between hunger and poverty and reasons that hunger results because of poverty and both have negative impacts on any society they exist in. A hungry nation is a weak nation both economically and politically.

\section{Anambra and the COVID-19 hunger challenge}

Anambra State, located in the south eastern part of Nigeria, was founded on 27 August 1991 with Awka as the capital city. Former state governor of Anambra State, Peter Obi, whilst making a donation of COVID-19 
palliatives to the state, described Anambra as a state that has economic and commercial importance to Nigeria and therefore deserves to have a lasting COVID-19 laboratory in place (Ujumadu 2020a).

Anambra indigenes, who are mostly Igbo people, are known for their strong religious inclinations. They have diverse religious beliefs. There are traditional religious adherents, and other forms of religion are tolerated within the state. Christianity seems to be the more outstanding and predominant religion as Ezeonwu (2011:493) and Adamu et al. (2011:6) observed. The arrival of COVID-19 infected Italians in Nigeria on 27 February 2020 brought tension and fear to the entire nation. In order to stop the spread of the virus, which was already threatening China and other countries, the federal government announced a lockdown of all the schools in the country from 23 March 2020 and restricted the operation of all social and religious gatherings. Anambra reinforced the lockdown according to Ujumadu (2020b) by not only closing all schools, but also by ordering the civil servants to remain at home. The borders they share with six states were shut; restricting people from entering the state. The Commissioner for Information and Public Enlightenment, Mr Adinuba, announced the further closure of 63 major markets from 31 March 2020 with the exception of foodstuff and medicine shops. People were advised through the social media and news broadcasts to practise social distancing, washing and sanitising of their hands regularly and to desist from social gatherings. Weeks before the lockdown, people were forewarned and advised to stock foodstuffs in their homes.

The entrance of the infection into the state led the state government to enforce and make the lockdown more severe, forcing the people to stay at home for another two weeks but before the completion of the two weeks, people trooped out from homes of various cities defying the lockdown order. Their complaint was that hunger resulting from the lockdown was becoming more severe than the pandemic. Most of these people were artisans and those who depend on their daily income to sustain themselves.

Eleweke (2020) reports that the Anambra State governor, Willie Obiano, has lifted restrictions within the state but lockdown on boundaries has not been lifted. Food markets, bars and restaurants are to reopen immediately, however, business owners must adhere to all COVID-19 protocol. $\mathrm{He}$ did this to save people from starving and also to avoid the breakdown of security.

Lockdown in the state collapsed businesses, especially those who were not selling food items, medicines or farm products. The COVID-19-inflicted hunger was unique as even rich businessmen were heavily affected because their source of income was shut off. People appealed to churches demanding food, and most churches established food banks from where they collect and distribute food to the hungry.
TABLE 1: Table showing (some) donated and distributed COVID-19 palliatives in Anambra State.

\begin{tabular}{|c|c|c|}
\hline Palliative sources & $\begin{array}{l}\text { Items received and } \\
\text { beneficiaries }\end{array}$ & Distribution strategy \\
\hline 1. Federal government & $\begin{array}{l}180050-\mathrm{kg} \text { bags of rice and } \\
240 \text { cartons of tomatoes to } \\
\text { the indigent }\end{array}$ & Not given \\
\hline \multirow[t]{2}{*}{ 2. State government } & $\begin{array}{l}36000 \text { bags of rice to the } \\
\text { elderly above } 70 \text { years. } \\
\text { Each local government } \\
\text { received } 200 \text { bags }\end{array}$ & $\begin{array}{l}\text { Project Monitoring and } \\
\text { Management Office } \\
\text { (PMMO), the town's } \\
\text { president generals, women } \\
\text { representatives, house } \\
\text { members from their areas }\end{array}$ \\
\hline & $\begin{array}{l}400 \text { bags of rice were } \\
\text { received by the youth }\end{array}$ & $\begin{array}{l}\text { Distributed through } \\
\text { community youth leaders }\end{array}$ \\
\hline \multirow{2}{*}{$\begin{array}{l}\text { 3. People's Democratic } \\
\text { Party (PDP) and } \\
36 \text { donors }\end{array}$} & 125 million & - \\
\hline & $\begin{array}{l}\text { Promise to build a test } \\
\text { centre for the state each } \\
\text { community to receive } \\
\text { } 300000,60 \text { poor families } \\
\text { to receive } 105000 \text { local } \\
\text { governments for the second } \\
\text { phase }\end{array}$ & \\
\hline \multirow[t]{3}{*}{$\begin{array}{l}\text { 4. Churches/dioceses, } \\
\text { parishes and } \\
\text { parishioners }\end{array}$} & $\begin{array}{l}\text { Over } \$ 30 \text { million, bags of } \\
\text { rice, beans, cartons of } \\
\text { noodles and face masks to } \\
\text { more than } 5000 \text { indigent } \\
\text { families }\end{array}$ & $\begin{array}{l}\text { Church group leaders, } \\
\text { church workers and } \\
\text { special appointees }\end{array}$ \\
\hline & $\begin{array}{l}\text { Both church members and } \\
\text { the hungry in general }\end{array}$ & \\
\hline & HIV-positive persons & \\
\hline $\begin{array}{l}\text { 5. Community } \\
\text { interventions, clubs, } \\
\text { NGOs and individual } \\
\text { donations }\end{array}$ & To Anambra residents & $\begin{array}{l}\text { Given to the less privileged } \\
\text { in the community }\end{array}$ \\
\hline \multirow[t]{3}{*}{$\begin{array}{l}\text { 6. Dr Mrs. Ebelechukwu } \\
\text { Obiano }\end{array}$} & $\begin{array}{l}200 \text { bags of rice, } 210 \text { bottles } \\
\text { of } 250 \mathrm{~mL} \text { sanitisers, } 100 \\
\text { cartons of noodles, vegetable } \\
\text { oil, tomatoes, salt and onions }\end{array}$ & $\begin{array}{l}\text { Given directly to the } \\
\text { community }\end{array}$ \\
\hline & 200 families in Ifite Ogbunike & \\
\hline & Sickle cell and HIV-positive & \\
\hline
\end{tabular}

The information in Table 1 is drawn from reports and oral communication, and is not exhaustive (see sources below). ${ }^{1}$

Table 1 is a summarised version of the assistance provided by the federal and state government, church, communities and individuals. Rt. Rev. Dr Owen Nwokolo, in addition to the various aids given by his parishioners at the parish level, gave over 30m to support over 5000 suffering families apart from the food items listed in the table. He also reached out to people with HIV, as reported by Rev. C. Okonkwo, the bishop's chaplain (All Saints Cathedral Onitsha, 23 June 2020). Many churches from other dioceses felt that their contributions should not be disclosed. Individuals made huge contributions to their communities and as donations to support the state. Donations of philanthropists to the state made a big impact in lessening the suffering of people. One

1.Okonkwo, E., 2020, 'Federal govt donates COVID-19 palliative to Anambra state'. See https://www.absradiotv.com/2020/05/09/federal-govt-donates-covid-19palliative-to-anambra-state/.

Ujumadu, V., 2020c, 'COVID-19: Obiano distributes 36,000 bags of rice to Anambra septuagenarians'. See https://www.vanguardngr.com/2020/03/covid-19-obianodistributes-36000-bags-of-rice-to-anambra-septuagenarians/.

Ujumadu, V., 2020d, 'COVID-19: Peter Obi, Obaze, others donate 125 million to Anambra, PDP relief fund'. See https://www.vanguardngr.com/2020/05/covid-19palliative-obi-others-donate-n125m-to-anambra-pdp/.

Information was received from Rev. Chidi Okonkwo (bishop's chaplain, All Saints Cathedral, Onitsha), Ven Dr Rex Kanu (Church of the Holy Spirit, Awka) and Rev. Ikenna (Elochukwu Akolisa, Cathedral Church of St Mary, Nnewi).

Anaeze, G., 2020, 'COVID-19: Business mogul donates billions, 27,000 bags of rice to

Anambra residents'. See https://independent.ng/covid-19-business-moguldonates-billions-27000-bags-of-rice-to-anambra-residents/.

Okoye, I., 2020, 'Mrs Obiano gives palliative support to 200 families in Umuonyema Okoye, l., 202.' 'Mrs Obiano gives palliative support to 200 families in Umuon
Ogbunike'. See https://www.thenigerianvoice.com/thread/72965/287610/1

Nwaiwu, C., 2020, 'COVID-19: Osumenyi families, youths, receive palliatives from Gov. Obiano'. See https://www.vanguardngr.com/2020/05/covid-19-osumenyi-familiesyouths-receive-palliatives-from-gov-obiano/. 
major limitation of this research is that, despite the palliatives distributed, many people still seek food assistance from churches. Many churches demand food contributions for their food bank. The author's communication with B. Umeaku (Afo market, Ezinifite, 14 May 2020) and U. Orabuche (Isuofia village) revealed lapses in food sharing and poor logistics.

One major laudable step taken by the Anambra State government is the continuous campaign for farming, to prevent impending famine that could arise as a result of COVID-19. Constant encouragements to people to engage in the farming popularly described as Ugbo-Azuno [backyard farming] is broadcast by Anambra Radio Station during the news broadcast. This is a further measure to lessen hunger and ensure food sufficiency.

\section{The book of Luke}

Having therefore established in this study that hunger is prevalent in the state, the next step is to examine a typical strategy employed in the biblical world for effective hunger reduction. To do this, the account of how Jesus addressed some hungry crowds as Luke records it are subjected to analysis (similar accounts are stated in all the gospels: Mt 14:13-2; Mk 6:30-44; Jn 6:1-14).

The gospel of Luke has a strong attestation of Luke's authorship. The writer of Luke is regarded as Lucan-Acts. Seven major ancient witnesses - Muratorian canon, Irenaeus, late second century prologue to the gospel, Tertullian, Origen, Eusebius and Jerome concurred to the authorship of the book by Luke, according to Karris (2000:675). These sources agree that Luke who is a native of Syria of Antioch - authored the book. Dating the book between AD 66 and 70, that is, soon before the Jewish war and the destruction of Jerusalem in 70 AD (Lk 21:5-38), seems logically right. Foxwell Albright, according to Boshoff (n.d:37), dated the book between AD 50 and 75.

Luke's literary style and sitz in leben depicts a mastery of Greek evidenced in his elegant Greek writing (1:1-4) and the Septuagint Greek (1-:5-2:52). He adapts Greek literary forms to convey his message, for instance the symposium genre in 7:36-50 and 11:37-54. In Luke 22:14-38 and Acts 20:17-38, he expressed his genre in a farewell discourse. Karris (2000:676) said that Luke wrote for a Gentile audience and this is apparent throughout the book. He presents Jesus as the one who can reconcile all those who through faith approach him. In fact, according to Stamps (1992), in Luke's gospel, Jesus is clearly portrayed as the divine-human saviour sent by God for the salvation of all of Adam's descendants. Krol (2014) added that what distinguishes Luke's gospel is Jesus' care for the poor and marginalised of the society and his reception to the Gentiles, the unclean, the poor, women, Samaritans, rich toll collectors and others. Jesus made it clear that he came to save the lost and poor (Lk 4:18ff.; Lk 19:10); outcasts can be included in the promises of Israel and now become the reconstituted Israel.
Luke upheld Judaism and places Christianity upon Judaistic tradition (Lk 16:17 \& Ac 21-26). For Luke, Jesus and his community of followers stand in the noble tradition of Judaism and even though sometimes he lays aside prescriptions of the law, he upheld Judaism.

\section{Close reading of the feeding Pericope: Luke 9:10-17}

The general context within which the miracle of feeding 5000 people happened focussed on the question of the identity of Jesus. The miracle helped to answer that question. Jesus had been teaching and healing people (Lk 8) and in Chapter 9 he sends out the 12 apostles and gives them power and authority over all demons and to cure diseases. They were to 'preach the kingdom of God and heal the sick' (9:1-2). The fame of Jesus was widespread and this made Herod wonder and question 'who is this, about whom I hear such things?' (9:9).

9:10 The feeding of the 5000 starts with the return of the oi

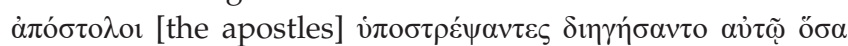
$\dot{\varepsilon} \pi$ oín $\sigma \alpha v$ [who on return from their mission related to Jesus whatever they had performed]. The word ö $\sigma \alpha$ which means 'whatever' implies that they gave Jesus a thorough account of the exercise they carried out by his authority. It was a tedious task that included preaching the kingdom of God, healing sick people and casting out all demons (Lk 9:12). They were instructed to take no provisions, namely money, bread, staff and a bag for the journey. The apostles likely must have returned both exhilarated and exhausted even though they made significant progress.

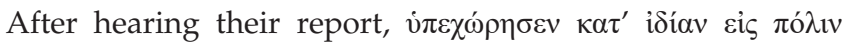

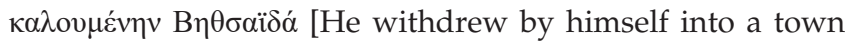
called Bethsaida]. Jesus retired with them to the town of Bethsaida because he knew that the Passover was approaching, the apostles have performed tiring work and there was a need for rest and refreshment, therefore Jesus called for rest. The withdrawal was a voluntary action that Jesus took, hence Luke reports that he made it 'by himself'.

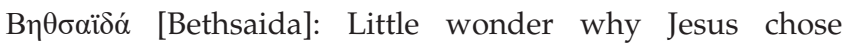
Bethsaida as a place of relaxation? Bethsaida is believed to be located on the Northern shore of the sea of Galilee (Pfister 2019:1). As they sought solitude, the place appeared to be remote. Pfister (2019:1) explained that Bethsaida is significant in the ministry of Jesus for the fact that he had performed some of his most indelible miracles there and three of his disciples - Philip, Peter and Andrew, came from there (Jn

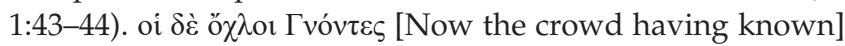
from the verb or word ginosko 'to come to know', 'recognise', 'perceive', 'to ascertain' and 'realise'. When they learnt by personal experience that Jesus had moved to Bethsaiada,

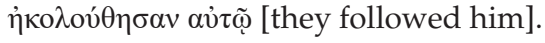

9:11 Jesus addresses the spiritual hunger of the crowds:

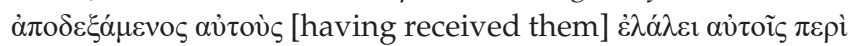

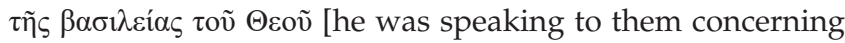
the kingdom of God]. Jesus did not send them back 
although he desired to be alone, instead he (Meyer n.d. ${ }^{2}$ ) welcomed them without a sign of impatience and spoke to them concerning the kingdom. He was able to see the plight of the crowds beyond what the apostles saw. He rather taught and healed those who had a need for healing. The action of Jesus exemplifies the Lucan theme, which is caring for the poor, the oppressed and the marginalised of society (Lk 4:18-19;19:10). The Lucan Jesus had profound compassion for the poor and downtrodden, the sick and hurt, the Samaritans and other outcasts (Boshoff n.d.:20, Karris 2000:676; Krol 2014). Jesus addressed the spiritual need of the crowds by first teaching them about the kingdom and healing the sick amongst them. This action of Jesus is remarkable because he gave a holistic touch to their needs.

9:12 Jesus addresses the psychological and emotional hunger of

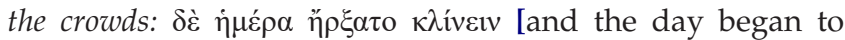
decline]. When evening came, only Luke used the word $\kappa \lambda$ iveıv [decline], the day went down suggesting the arrival of evening. The apostles suggested that the crowd be dismissed.

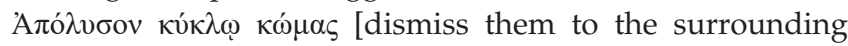
villages]. The suggestion of the 12 apostles that the crowd be dismissed was not that they should be driven away totally, instead they were to go to the surrounding villages for provision. The apostles' suggestion is not out of place because it was natural for them to reason along that line. They showed concern by proposing practical solutions for the immediate need. The refusal of Jesus to listen to the suggestion of the 12 apostles here is a reflection of Jesus' benevolent hospitality to the poor and hungry masses. Krol (2014) stressed the hospitality of Jesus, which he demonstrated by providing not just food but also lodging for the crowd.

9:13 Jesus challenges his apostles to provide to the hungry world:

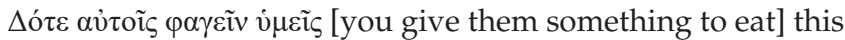
was Jesus's response to his disciples. Why should Jesus challenge his disciples in this manner when he was aware of their scanty resources? To this, many have tried to provide explanations. Harrison (1981) for instance reasoned that Jesus wanted the disciples to estimate their own resources and to use what they had. For Francis (2010), Jesus needed the collaboration of his disciples in feeding the deep hunger of people. Francis' view is shared by Larson (1983:169) who saw a call for responsibility in Jesus' demand. The attention of his disciples was also drawn to the fact that they should shoulder the responsibility of meeting the diverse needs of the people over above their own needs. Jesus teaches the disciples a lesson on responsible service, faith and submission. not trust God only when they can conceive how the resources would be provided, but even when its provision is unimaginable. The 12 apostles handed five loaves of bread and two fish to him and having taken them, he blessed them.

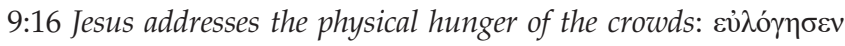

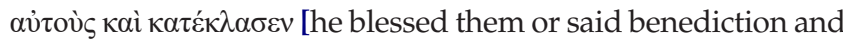
broke them] (Meyer n.d.). Moloney (n.d.) observed that Jesus did not feed the crowd until they had been arranged in groups of fifty, depicting orderliness. Luke made it clear that he blessed and broke the food, giving it to his apostles to share. MacLaren (n.d.) adds that the food kept increasing in the hands of the disciples who distributed them. He also sees a symbolism in the bread. Poon (2003:224) and Moloney (n.d.:2) equally argued along the Eucharistic implication of the feeding. Poon also maintained a case of the identity of Jesus and superabundance of food from Jesus' feeding, which he emphasised over and above the satisfaction of hungry people.

Poon's (2003) position on the Lucan feeding of 5000 as a display of Jesus' identity and Luke's meal motif are both logical. However, convincing they may appear, the fact that Jesus addressed the spiritual and physical hunger of the crowds that gathered around him should not be undermined.

The crux of this study rests on the fact that Jesus addressed both the spiritual, physical, psychological and emotional hunger of the crowd. The Lucan Jesus, as Karris (2000:676) identified him, upheld the mitzvah or law of Judaism in his ministry. He did not come to destroy the law but to fulfill it (Mt 5:17). Judaism demands the feeding of the hungry as the most important service to God. The challenge of feeding the hungry is fundamental to the Jewish society where Jesus came from (Schwartz 2017:4). In fact, feeding hungry people is so important in Jesus' social setting that the legacy is now being transferred to the children as recorded in Shalom Sesame (Posen 2017) and other sources of communication.

\section{Lucan's feeding of $\mathbf{5 0 0 0}$ men in the context of Anambra's COVID-19 hunger challenge}

Lucan's feeding of 5000 people involved a collection of people described as crowds (ő $\chi \lambda \mathrm{ol}$ ). These people trooped down to Bethsaida on the awareness that Jesus was going there. As the composition of Jesus' followers normally are, they must have followed to receive his teachings and other material benefits. We can simply say that they lacked something (their lack is not specifically mentioned in the text). Jesus provided them with spiritual food through the word, healings and eventually physical food. In the case of Anambra's COVID-19-related hunger, there are also crowds that lack food in particular and other COVID-19 palliatives. The Anambra hunger challenge was occasioned by the lockdown measures. The palliatives that people received were donations from federal and state governments, churches, humanitarians, clubs, political parties and some town chiefs. In each of the cases there was a supply of food items. Whilst that of Jesus was multiplied by an act of miracle leading to abundance and excess supply, Anambra's food supplies were distributed based on the available donations and there was no abundance nor surplus.

The pericope emphasised that man's spiritual needs should be addressed alongside his physical needs and Jesus understood this principle. Jesus gave them the spiritual word and healed their diseases, thus creating a good atmosphere 
for physical satisfaction, but in Anambra such principle is rarely followed. Jesus had to acknowledge God's provision of food by giving him thanks and the blessing of the five loaves and two fish. The divine intervention was obvious as food increased consistently until it became excess.

The Lucan account shows that food distribution was well organised through grouping the recipients in fifties and appointing honest sharers - the apostles. Supervision of the exercise (which was supposedly performed by Jesus) minimised lack of satisfaction and complaint. The problem of inequitable distribution and even total denial of palliatives were reported during the COVID-19 palliative distribution because of poor distribution strategies.

In line with the issue of spirituality discussed here, the crowds that followed Jesus (who were eventually fed) were people who thirsted after righteousness, not just a crowd gathered for the purpose of collecting food items. Most of the hungry crowds in the state are interested merely in physical food collection. If people seek God first, they are assured of sufficient supply of other life demands (Mt 6:33).

The Lucan story portrays the commitment of Jesus to satisfying the pressing needs of others. They forfeited their comfort and rest, and even sacrificed their food for other people's needs. This is very rare in the state.

\section{Lessons from the Lucan feeding of $\mathbf{5 0 0 0}$ men by Jesus to Anambra State and recommendations}

Much effort has been made in the state to address hunger and poverty but there has always been the problem of lack of grassroot touch (items are not always distributed to the people they are meant for). Items provided for the poor usually get diverted and/or mismanaged. Jesus supervised the distribution of the food to make sure that it got to everybody. In the same way, food or palliative providers should ensure that what they donate eventually get to the indigent people by supervising or monitoring the exercise.

The state should involve a combination of spirituality in feeding the hungry people as Jesus did. Feeding people with the word of God would to a large extent solve the problem of greed and insatiability on the part of the recipients.

Religious leaders, pastors and ministers are challenged to be sensitive to the psychological and emotional needs of their followers and provide solutions as Jesus exemplified in the account.

If those who steal (food or palliative distributors) the food donated to the poor are made to understand the need and the blessings derived from feeding hungry people, most likely, the problem of diversion of foods would be reduced.

Jesus demonstrates that feeding hungry people is a very important duty of man to God.
Church leaders and ministers who extort their members must realise that they are doing a disservice to God.

The involvement of the apostles in the feeding was to prepare their minds to the fact that we ought to provide for the needs of our followers no matter the situation, circumstance and environment we find ourselves in.

\section{Conclusion}

Coronavirus disease 2019, as named by the WHO, surfaced on 01 December 2019 and within a short period began to spread with seemingly uncontrollable speed. This novel virus that records an unprecedented manner of infection is currently a world threat. One of the surest ways of containing it and minimising its spread is the locking down of business centres, markets, shops and banning of social and religious gatherings. The disease affected individuals and companies in the state and impoverished many, resulting in many people seeking aid from the government and the Church.

The hunger situation in Anambra state has received many interventions in the form of food donations (other relevant COVID-19 items inclusive) from federal and state governments, churches, non-governmental organisations, clubs, communities, political parties, political aspirants and individuals. Donations are still ongoing. Research carried out on how the state addressed this peculiar hunger challenge, showed that many beneficiaries were excluded because of the logistics in the distribution, whilst the hunger challenge persists in the state. Only the palliatives distributed by the church and by some communities reached the appropriate quarters.

It is the submission of this article that the lessons drawn from Jesus' feeding of 5000 people be implemented in Anambra State where applicable. Some of the lessons are: (1) attending to people's spiritual hunger through scriptural and moral teachings, (2) ensuring proper supervision of food distribution, (3) sharing food items through organised groups, (4) creating awareness that feeding hungry people is one of the greatest services we can render to God and that this attracts huge blessings and (5) church leaders and ministers should be sensitive to the physical, psychological and emotional needs of their followers and address them aptly. There is a need for a drastic reduction of the COVID-19-engineered hunger in Anambra State. The state governor Chief Willie Obiano's campaign on Ugbo-azuno is a giant stride taken to avert famine in the near future. Whilst this is commendable, there is a need for implementation of well-structured agricultural projects and other practical measures.

\section{Acknowledgements}

The author would like to express her profound appreciation to Prof. Dr Ernest van Eck for his huge contribution. He finetuned the article by proof reading and making valid criticisms. Others who made significant contributions are Ven Dr Rex Kanu who provided data for his church's 
contribution on palliative distribution. Rev. Ikechukwu Akolisa and Rev. Chidi Okonkwo assisted with information on Nnewi and Onitsha dioceses. The author is most grateful to them.

The author would like to thank Mr Benjamin Umeaku, Bendette Nwosu and Janet Orabuche who allowed her to interview them. The author appreciates the prayer support of Ven Egwuenu of St. Thomas Church, Otolo, Nnewi.

Mr Ogemdi Echeta contributed immensely in the typing and computing consultations, which made the work faster. Odinaka Echeta, who lectures at the University of Lagos, assisted in preparing the work physically, spiritually and through general encouragement.

The author sincerely acknowledges the wealth of information she gathered from Anambra Broadcasting Station.

\section{Competing interests}

The author declares that they have no financial or personal relationships that may have inappropriately influenced them in writing this article.

\section{Author's contributions}

U.F.E. is the sole author of this article.

\section{Ethical considerations}

This article followed all ethical standards for research without direct contact with human or animal subjects.

\section{Funding information}

This research received no specific grant from any funding agency in the public, commercial or not-for-profit sectors.

\section{Data availability}

Data sharing is not applicable to this article as no new data were created or analysed in this study.

\section{Disclaimer}

The views and opinions expressed in this article are those of the author and do not necessarily reflect the official policy or position of any affiliated agency of the author.

\section{References}

ActionAid, 2020, Action against Hunger? Act-USA is recognized501 Not for profit organization by the IRS, viewed 04 March 2020, from http://www. actionagainsthunger.org.

Adamu, F., Ajala, O.A., Para-Mallam, J.O. \& Lanre-Abass, B. 2011 ‘Engagement of women's movements with religion: Legal reform in Anambra state, Nigeria', Unpublished working paper 60, Religions and Development Research Programme, s.n., s.l.

Anaeze, G., 2020 'COVID-19: Business mogul donates billions, 27,000 bags of rice to Anambra residents', Independent, viewed 15 June 2020, from https:// independent.ng/covid-19-business-mogul-donates-billions-27000-bags-of-riceto-anambra-residents/.
Beasley, D.M., 2020, Covid-19 could detonate a 'hunger pandemic'. With millions at risk, the world must act, viewed 17 May 2020 from https://www.washingtonpost. risk, the world must act, viewed 17 May 2020, from https://www.washingtonpost. millions-risk-world-must-act/.

Boshoff, R.P., n.d., The Gospel of Luke, viewed 03 June 2020, from https://www. academia.edu/4246062/The_Gospel_of_Luke.

Butler, T.C., 1991, Holman Bible dictionary, Broadman \& Holman, Nashville, TN, viewed 14 June 2020, from https://www.studylight.org/dictionaries/hbd/h/ hunger.html.

Da Silva, G.J., Houngbo, G.F., Fore, H., Beasley, D. \& Ghebreyesus, A., 2019, World hunger is still not going down after three years and obesity is still growing, UNICEF, viewed 13 June 2020, from https://www.unicef.org/press-releases/world-hungerstill-not-going-down-after-three-years-and-obesity-still-growing-un.

Echeta, U.F., 2020, 'A biblical approach to the reduction of child poverty in Anambra state, Nigeria', HTS Teologiese Studies/Theological Studies 76(4), a5565. https:// doi.org/10.4102/hts.v76i4.5565

Ejikeme, J.O., Ojiako, J.C., Onwuzuligbo, C.U. \& Eze, F.C., 2017, 'Enhancing food security in Anambra state, Nigeria, using Remote Sensing Data', Environmenta Review 6(1), 27-44.

Eleweke, T., 2020, 'Nigeria: Anambra lifts COVID-19 lockdown', Daily Trust, viewed 16 June 2020, from https://allafrica.com/stories/202004260012.html.

Elochukwu, C.U., 2016, 'Poverty and malnutrition: Trends an implications in Nigeria', International Journal of Research studies in Agricultural Sciences 2(9), 1-5. https://doi.org/10.20431/2454-6224.0209001

Ezeonwu, M.C., 2011, 'Maternal birth outcomes: Processes and challenges in Anambra state Nigeria', Health Care for Women International 32 (6), 492-514. https://doi.or $\mathrm{g} / 10.1080 / 07399332.2011 .555827$

Food and Agricultural Organization (FAO), 2019, World hunger is still not going down after three years and obesity is still growing - UN report, viewed 05 May 2020, from http://www.fao.org/asiapacific/news/detail-events/en/c/1201906/.

Food and Agriculture Organization (FAO), World Food Programme (WFP) \& European Union (EU), 2018, World hunger again on the rise driven by conflict and climate change, new UN report says, viewed 15 March 2020, from worldhunger.org/ world-hunger-and-poverty-facts-and-statistics.

Francis, L., 2010, 'Five loaves and two fishes: An empirical study in psychological type and biblical hermeneutics among Anglican preachers', HTS Teologiese/Theological Studies 66(1), Art, \#811. https://doi.org/10.4102/hts.v66i1.811

Harrison, E.F., 1981, The New Testament and Wycliffe Bible commentary, Moody Press, Chicago, IL.

Karris, R.J., 2000, 'The gospel according to Luke', in E. Raymond, S.S. Brown, A. Joseph, S.J. Fitzmyer, E. Roland \& O. Murphy (eds.), The new Jerome biblical commentary, pp. 676-677, Burns and Oates, India.

Krol, P., 2014, The feeding of 5,000 according to Luke, viewed 23 July 2020, from https:// www.knowableword.com/2014/01/27/the-feeding-of-5000-according-to-luke/.

Larson, B., 1983, 'Luke', in L.J. Ogilvie (ed.), The preacher's commentary, Thomas Nelson' Publishers, Nashville, TN.

Liu, Y.C., Kuo, R.L. \& Shih, S.R., 2020, 'COVID-19: The first documented coronavirus pandemic in history', Biomedical Journal 43(4), 328-333.

Macalister, A., 1939, 'The meaning of hunger in the Bible', in J. Orr (ed.), International Standard Bible Encyclopedia, viewed 09 June 2020, from https://www.bibletools. org/index.cfm/fuseaction/Def.show/RTD/ISBp675-667E/ID/4479/Hunger.html.

MacLaren, A., n.d., MacLaren expositions of holy scriptures, viewed 08 June 2020, from https://biblehub.com/commentaries/maclaren/luke/9.htm.

Meyer, H.W., n.d., Meyer's NT commentary, viewed 13 June 2020, from https:// biblehub.com/commentaries/meyer/.

Moloney, J., n.d., A narrative critical exegesis of the Lucan feeding of the five thousand viewed 07 May 2020, from https://www.academia.edu/13848580/A Narrative Critical_Exegesis_of_the_Lukan_Feeding_of_the_Five_Thousand.

Moss, A., n.d., Judaism is nice, but isn't it more important to feed the hungry?, viewed 02 May 2019, from https://www.chabad.org/library/article_cdo/aid/632129/ jewish/Isnt-it-More-Important-to-Feed-the-Hungry.htm

Nwafor, S., 2017, 'Anambra has the lowest poverty rate in Nigeria today - Obiano', Vanguard, viewed 04 May 2017, from https://www.vanguardngr.com/2017/08/ anambra-lowest-poverty-rate-nigeria-today-obiano/.

Nwaiwu, C., 2020, 'COVID-19: Osumenyi families, youths, receive palliatives from Gov. Obiano', Vanguard, viewed 17 May 2020, from https://www.vanguardngr. com/2020/05/covid-19-osumenyi-families-youths-receive-palliatives-from-govobiano/.

Okonkwo, E., 2020, 'Federal govt donates COVID-19 palliative to Anambra state' ABS Radio, viewed 09 May 2020, from https://www.absradiotv.com/2020/05/09/ federal-govt-donates-covid-19-palliative-to-anambra-state/.

Okoye, I., 2020, 'Mrs Obiano gives palliative aupport to 200 families in Umuonyema Ogbunike', The Nigerian Voice, viewed 16 June 2020, from https://www. thenigerianvoice.com/news/287610/mrs-obiano-gives-palliative-support-to-200families-in-umuon.html.

Pfeiffer, C.F., Vos, H.F. \& Rea, J., 2005, Wycliff Bible dictionary, Hendrickson Publishers, Inc., Peabody, MA.

Pfister, S.D., 2019, 'Where is biblical Bethsaida?' Bible History Daily, viewed 08 June 2020 from https://www.biblicalarchaeology.org/daily/news/where-is-biblical-bethsaida/.

Poon, W.K., 2003, 'Superabundant table fellowship in the kingdom: The feeding of the five thousand and the meal motif in Luke', The Expository Times 114(7), 224-230. https://doi.org/10.1177/001452460311400703 
Posen, E., 2017, 'It's a Mitzvah - Feeding the Hungry', YouTube, viewed 01 June 2020, from https://www.youtube.com/watch?v=YUqKUjU1hss.

ReliefWeb, 2020, Coronavirus: Millions facing hunger around the world, viewed 15 June 2020, from https://reliefweb.int/report/world/coronavirus-millions-facinghunger-around-world.

Schwartz, R., 2017, 'Judaism, vegetarianism, and feeding the hungry', The Times of Israel, viewed 17 June 2020, from https://blogs.timesofisrael.com/judaismvegetarianism-and-feeding-the-hungry/.

Stamps, D.C. \& Adams, J.W., 1992, The full life study: New International Version, Zondervan, Grand Rapids, MI.

Tripathi, R., 2020, 'Respecting, protecting, fulfilling the right to food in times of Covid-19', ActionAid International, viewed 15 March 2020, from https://actionaid. org/opinions/2020/respecting-protecting-fulfilling-right-food-times-covid-19.

Ujumadu, V., 2020a, 'COVID-19 palliative: Obi, others donate N125m to Anambra PDP', Vanguard, viewed 17 May 2020, from https://www.vanguardngr. com/2020/05/covid-19-palliative-obi-others-donate-n125m-to-anambra-pdp/.

Ujumadu, V., 2020b, '[Breaking] Coronavirus: Anambra closes 63 markets for 2 weeks', Vanguard, viewed 16 June 2020, from https://www.vanguardngr.com/2020/03/ breaking-coronavirus-anambra-closes-63-markets-for-2-weeks/.
Ujumadu, V., 2020c, 'COVID-19: Obiano distributes 36,000 bags of rice to Anambra septuagenarians', Vanquard, viewed h.d. from https://www.vanguardngr. com/2020/03/covid-19-obiano-distributes-36000-bags-of-rice-to-anambraseptuagenarians/.

Ujumadu, V., 2020d, 'COVID-19: Peter Obi, Obaze, others donate 125 million to Anambra, PDP relief fund'. Vanguard, viewed n.d., from https://www. vanguardngr.com/2020/05/covid-19-palliative-obi-others-donate-n125m-toanambra-pdp/.

Ukpokolo, C., 2016, 'Economic survival, masculinity and shifting cultural definition of the woman's identity in rural Igbo society', in Being and becoming: Gender, culture and shifting identity in sub-Saharan Africa, pp. 111-136, Spears Media Press, Denver, CO. https://doi.org/10.2307/j.ctvh8r09w.10

Van der Merwe, D., 2015, 'Reading the Bible in the 21st century: Some hermeneutical principles: Part 2', Verbum et Ecclesia 36(1), Art. \#1392, 7 pages. http://doi. org/10.4102/ve.v36i1.1392

Walter, W., 1957, 'Hunger', in Wilson's dictionary of Bible types, viewed 06 September 2020, from https://www.studylight.org/dictionaries/eng/wdt/h/hunger.html.

Willis, J.R., 1915, 'Hunger', Hastings' dictionary of the New Testament, viewed 14 June 2020, from https://www.studylight.org/dictionaries/eng/hdn/h/hunger.html. 